\title{
ANALISIS FAKTOR-FAKTOR YANG MEMENGARUHI KETERSEDIAAN BERAS DI INDONESIA
}

\author{
ANALYSIS OF FACTORS THAT INFLUENCE \\ RICE AVAILABILITY IN INDONESIA
}

\author{
Ahmad Ilyas", Melinda Noer, Ira Wahyuni \\ Program Studi Ilmu Ekonomi Pertanian Pascasarjana Fakultas Pertanian, Universitas Andalas \\ Kampus Unand, Limau Manis, Kec. Pauh, Kota Padang, Sumatera Barat 25163 \\ *E-mail: ahmadilyas1882@gmail.com \\ (Diterima 28-04-2020; Disetujui 19-06-2020)
}

\begin{abstract}
ABSTRAK
Beras merupakan komoditas pangan strategis di Indonesia. Gangguan terhadap ketersediaan beras akan mengganggu stabilitas ekonomi, sosial dan politik di Indonesia. Penelitian ini bertujuan untuk melihat gambaran umum ketersediaan beras di Indonesia, serta mengindentifikasi dan menganalisis faktor-faktor yang memengaruhi ketersediaannya. Penelitian ini menggunakan data sekunder berupa data time series selama 14 tahun dari Januari 2004 sampai dengan Desember 2017. Data diolah menggunakan metode analisis deskriptif dan analisis jalur (path analysis) dengan menggunakan program Statistic Data Analysis (STATA). Gambaran umum menunjukkan peningkatan perkembangan ketersediaan beras di Indonesia setiap tahunnya dengan pertumbuhan 3,39\%. Peningkatan ketersediaan tersebut ditunjang oleh kebijakan-kebijakan yang telah dikeluarkan oleh pemerintah seperti kebijakan di sektor produksi berupa subsidi input (benih dan pupuk), sarana dan prasarana, subsidi output, Harga Pembelian Pemerintah (HPP), sektor impor berupa regulasi impor dan tarif impor. Analisis jalur (path analysis) terhadap model ketersediaan beras Indonesia didapatkan bahwa faktor produksi dan impor berpengaruh langsung dan signifikan terhadap ketersediaan beras di Indonesia.
\end{abstract}

Kata kunci: Impor, ketersediaan beras, produksi, subsidi

\section{ABSTRACT}

Rice is a strategic food commodity in Indonesia. Disruption to the availability of rice will disrupt economic, social and political stability in Indonesia. This research aims to see a general picture of rice availability in Indonesia, as well as identify and analyze factors that influence availability. This study uses secondary data in the form of time series data for 14 years from January 2004 to December 2017. The data is processed using descriptive analysis and path analysis using the Statistical Data Analysis (STATA) program. General description of the development of rice availability in Indonesia shows an increase every year with a growth of $3.39 \%$. The increased availability was supported by 'policies issued by the government such as policies in the production sector in the form of input subsidies (seeds and fertilizers), facilities and infrastructure, subsidized outputs for Government Purchasing Prices (HPP), the import sector in the form of import regulations and import tariffs. Based on a path analysis of the model of Indonesian rice availability, production and imports have a direct and significant effect on the availability of rice in Indonesia.

Keywords: Rice availability, production, imports, subsidies 


\section{PENDAHULUAN}

Kebutuhan pangan merupakan kebutuhan dasar dan hak asasi setiap manusia. Setiap usaha untuk membangun kemandirian pangan yang kuat harus menjadi prioritas negara. Kemandirian pangan setiap negara dihadapkan tantangan peningkatan permintaan dan ketidakstabilan harga pangan pokok. Kondisi tersebut dapat menjadi ancaman krisis pangan dan perang pangan global. Food Agriculture Organization (FAO), International Monetary Fund (IMF) dan United Nation Population Fund (UNPF) menyatakan bahwa kondisi tersebut terjadi dipicu oleh laju pertumbuhan penduduk, peningkatan pendapatan, lompatan jumlah penduduk kelas menengah (terutama di Asia, Afrika, dan Amerika Selatan), pergeseran selera konsumsi, substitusi energi fosil, konversi lahan dan perubahan iklim global (Wahyu \& Iwan, 2017).

Salah satu kebijakan yang dipakai oleh banyak negara dalam menjaga kemandirian pangan adalah kebijakan swasembada pangan. Swasembda pangan adalah kemampuan negara memenuhi kebutuhan pangan dalam negeri yang bersumber dari produksi dalam negeri sendiri. Konsep swasembada pangan berfokus pada pasokan atau ketersediaan, kepastian suatu negara untuk memiliki kapasitas menghasilkan makanan dalam jumlah yang cukup untuk memenuhi kebutuhan dalam negeri (FAO 1999 dalam Clapp 2016).

Indonesia merupakan salah satu negara dengan populasi terbesar di dunia dengan beras merupakan pangan pokok hampir sebagian besar penduduknya. Komoditas beras dikenal sebagai komoditi thin market, sehingga harus dijaga ketersediannya. Beras dianggap komponen utama penyebab inflasi karena tingkat konsumsinya yang merata. Proposi pengeluaran negara untuk beras dan pangan lainnya masih dominan. Terganggunya ketersediaan beras akan mengganggu ketahanan pangan Indonesia (Leo, 2000).

Ketahanan pangan di Indonesia yaitu kondisi terpenuhinya pangan bagi negara sampai dengan perseorangan, yang tercermin dari tersedianya pangan yang cukup, baik jumlah maupun mutunya, aman, beragam, bergizi, merata, dan terjangkau serta tidak bertentangan dengan agama, keyakinan, budaya masyarakat, untuk dapat hidup sehat aktif dan produktif secara berkelanjutan (Undang-Undang nomor 18 tahun 2012 tentang pangan). Pemerintah harus menjamin ketersediaan beras dalam negeri sehingga selalu meletakkan program Swasembada Beras di 
dalam rencana pembangunan jangka menengah nasional (RPJMN) tahun 20152019.

Pemerintah harus meningkatkan ketersediaan beras dalam negeri dengan meningkatkan produksi melalui kebijakankebijakan yang merangsang peningkatan produksi melalui subsidi antara lain input (pupuk dan benih), output (HPP) sarana dan prasarana (sistem pengairan dan certak sawah), penggunaan varietas unggul serta pengenaan tarif bea masuk terhadap beras impor selain juga didukung oleh faktorfaktor alam yang cukup berpengaruh terhadap produksi (Kementan, 2015). Berbagai kebijakan pemerintah yang berpihak kepada produsen/petani telah terbukti mendorong peningkatan produksi dalam negeri sehingga berdampak positif terhadap ketersediaan beras.

Penelitian ini bertujuan untuk mengetahui gambaran ketersediaan beras di Indonesia dan menganalisis faktorfaktor yang memengaruhinya.

\section{METODE}

1. Metode Penelitian

Penelitian merupakan penelitian yang menggunakan data sekunder berupa data tahunan (time series) dengan rentang waktu dari Januari 2004 hingga Desember 2017. Data diperoleh dari beberapa instansi terkait, yaitu Badan Pusat Statistik (BPS), dan Kementerian Pertanian (Sekretariat Jenderal Kementan, Direktorat Tanaman Pangan, Direktorat Sarana dan Prasarana Pertanian, dan Badan Ketahanan Pangan, serta Pusat Data dan Informasi Kementan). Penelitian ini menggunakan metode deskriptif kualitatif. Sedangkan faktorfaktor yang memengaruhi ketersediaan beras dianalisis menggunakan metode path analysis. Data diproses menggunakan program STATA versi 12.

\section{Spesifikasi Model}

Analisis jalur (path analysis) bertujuan untuk mengetahui pengaruh langsung dan tidak langsung variabel penyebab terhadap sebuah variabel akibat. Analisis jalur merupakan pendekatan model persamaam struktural (SEM/ structural equation modelling) yang spesifik. Teknik SEM memungkinkan seorang peneliti untuk menguji beberapa variabel dependen sekaligus dengan beberapa variabel independen (Ferdinan, 2005).

Variabel di dalam penelitian merupakan variabel berkelanjutan (integer/continuos variabel). Hubungan antar variabel dapat divisualisasikan dengan diagram atau gambar dalam path analysis. Berdasarkan dugaan awal, base model dari faktor-faktor yang 
memengaruhi ketersedian beras Indonesia diilustrasikan oleh Gambar 1.

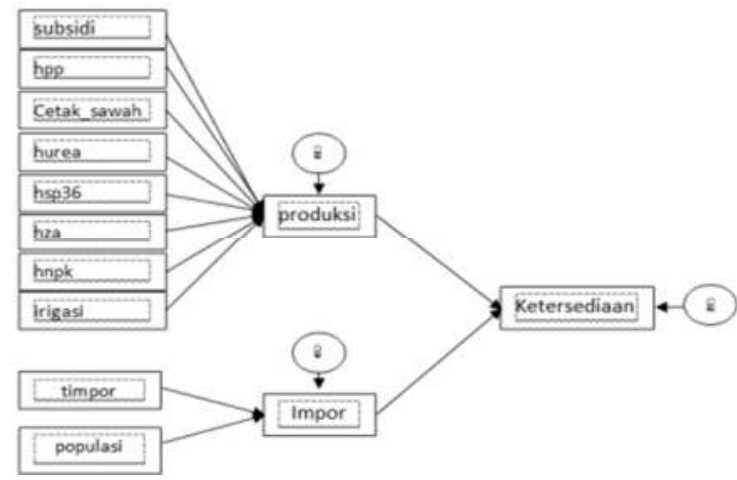

Gambar 1. Base Model dari Ketersediaan Beras

\section{HASIL DAN PEMBAHASAN}

\section{Perkembangan Ketersediaan}

Ketersediaan adalah salah satu elemen yang ada dalam aspek ketahanan pangan yang selalu menjadi perhatian oleh pemerintah. Kondisi perberasan di Indonesia dalam kurun waktu tahun 20042017 bisa dikatakan cukup baik, ditandai dengan terus meningkatnya ketersediaan beras di Indonesia (Gambar 2).

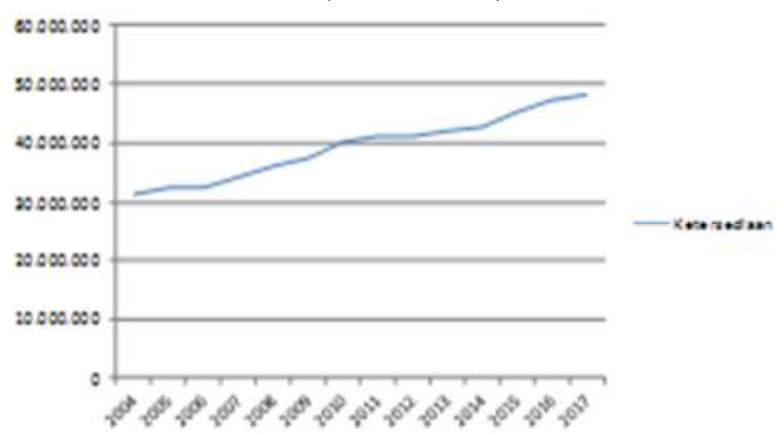

Gambar 2. Perkembangan Ketersediaan Beras Indonesia 2004-2017

Rerata peningkatan ketersediaan beras berkisar 3,39\% setiap tahunnya. Pertumbuhan ketersediaan tertinggi terjadi pada tahun 2007 dan 2015 dimana angka pertumbuhannya mencapai sekitar $6 \%$ dibanding tahun sebelumnya. Hal tersebut dikarenakan oleh produksi padi Indonesia mengalami peningkatan yang signifikan, yaitu 35.860 .570 ton di tahun 2007 dibandingkan tahun 2006 sekitar 34.165.030 ton. Peningkatan produksi tersebut tidak lepas dari revitalisasi pertanian yang dijalankan oleh pemerintah yang diarahkan untuk meningkatkan kemampuan produksi beras dalam negeri sebesar 90-95\% dari kebutuhan.

Pertumbuhan di tahun 2015 juga mencapai 6\% dibanding tahun sebelumnya. Hal tersebut disebabkan adanya peningkatan total produksi beras Indonesia di tahun 2015 (mencapai 47.304.608 ton) dibandingkan tahun 2014 (mencapai 44.449.070 ton). Peningkatan produksi tersebut terjadi disebabkan oleh keseriusan pemerintah untuk meningkatkan produksi padi melalui Upaya Khusus (UPSUS) dengan mengerahkan segala sumberdaya yang ada, baik anggaran yang meningkat dari tahun sebelumnya. Pemerintah juga melibatkan pemegang kepentingan di bidang pertanian termasuk Tentara Nasional Indonesia (TNI) dalam proses produksi padi/beras. Meningkatnya produksi padi/beras secara otomatis meningkatkan ketersediaan beras Indonesia. 
Selama periode pengamatan, hanya satu kali terjadi penurunan ketersedian yaitu di tahun 2006, ketersediaan turun $0,1 \%$ (24.000 ton) dibandingkan tahun 2005. Hal tersebut lebih banyak disebabkan karena faktor alam. Terjadinya bencana alam dibeberapa provinsi yang ada di Indonesia, seperti gempa bumi yang terjadi di Sumatera Utara dan DI Yogyakarta, banjir bandang dan tanah longsor yang terjadi Provinsi Aceh dan banjir yang terjadi di Provinsi Riau dan Provinsi Kalimantan Barat mengharuskan Bulog mengeluarkan cadangan beras pemerintah untuk menolong logistik masyarakat yang terkena bencana alam tersebut. Hal ini sedikit berdampak pada ketersediaan beras nasional.

\section{Perkembangan Produksi Beras}

Perkembangan total produksi beras Indonesia mengalami peningkatan yang fluktuatif dari tahun 2004 sampai dengan 2017. Rerata pertumbuhan produksi berkisar pada angka 3,20\%. Selama periode pengamatan, hanya terjadi dua kali penurunan produksi, yaitu tahun 2011 dan tahun 2014 dibanding tahun sebelumnya (Gambar 3).

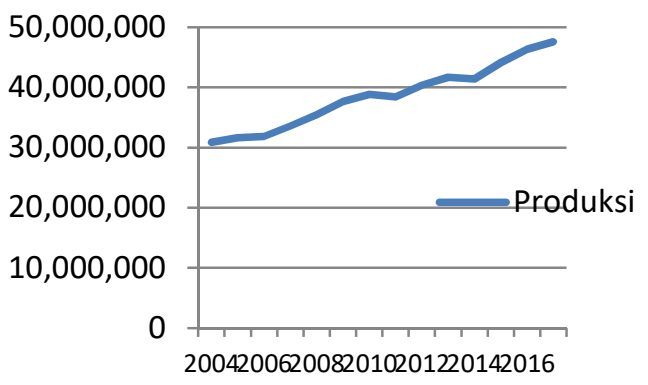

Gambar 3. Perkembangan Produksi Beras

\section{Subsidi Benih}

Benih padi yang diberikan subsidi oleh pemerintah adalah untuk padi inbrida. Besarnya subsidi benih yang diberikan pemerintah rata-rata setiap tahunnya meningkat. Peningkatan subsidi benih tersebut disesuaikan dengan anggaran yang tersedia. Selama periode waktu pengamatan penetian ini, sudah terjadi 9 (sembilan) kali perubahan nilai subsidi yang diberikan kepada petani yang diharapkan bisa menolong petani dalam menekan biaya produksi usaha taninya.

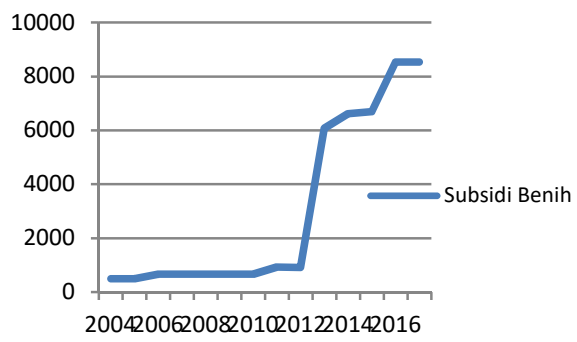

Gambar 4. Perkembangan Subsidi Benih Padi Inbrida

Peningkatan subsidi benih yang mencolok terjadi pada tahun 2013, peningkatan besaran subsidi benih sekitar Rp 6.073/kg atau tumbuh sebesar $571,05 \%$ dibandingkan tahun 2012 yang hanya sekitar Rp 905/kg. Besarnya kenaikan subsidi benih per kilogram yang diberikan oleh pemerintah disebabkan oleh meningkatnya anggaran APBN di lingkup Kementerian Pertanian untuk subsidi benih 
yaitu dari $R p$ 0,1 trilyun menjadi $R p$ 1,5 trilyun (Kementan, 2015).

\section{Harga Pupuk Subsidi}

Pengadaan pupuk bersubsidi ini ditujukan agar petani bisa meningkatkan kemampuannya dalam menerapkan pemupukan yang berimbang. Pemerintah sudah menetapkan harga ecera tertinggi untuk pupuk bersubsidi ini. Sehingga petani bisa membeli pupuk untuk kebutuhan usaha taninya dengan harga yang wajar. Pupuk subsidi yang ditetapkan HET-nya oleh pemerintah adalah pupuk urea, pupuk SP36, pupuk ZA dan pupuk NPK. Perkembangan harga HET pupuk bersubsidi sepanjang tahun pengamatan 2004-2017 (Gambar 5).

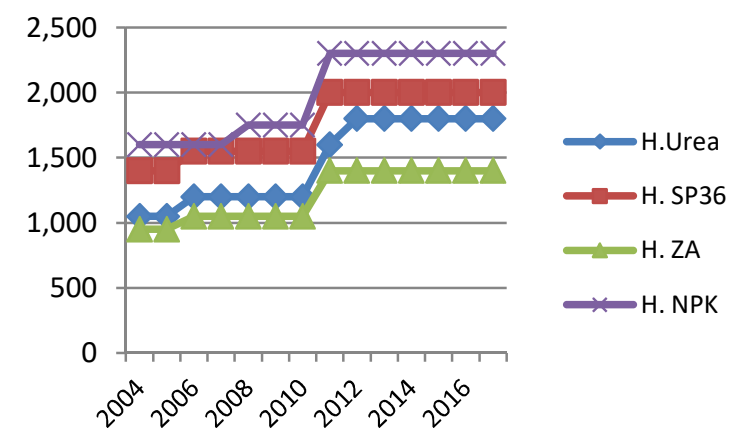

Gambar 5. Perkembangan Harga Pupuk Subsidi

Selama waktu pengamatan tersebut meskipun kecenderungan HET naik, tetapi kenaikkan tersebut tidak berlangsung setiap tahunnya, hal tersebut bertujuan untuk menjaga daya beli petani.

\section{Harga Pembelian Pemerintah (HPP)}

Pemerintah ingin memberikan insentif kepada petani padi dalam hal jaminan harga saat harga jatuh pada musim panen raya. HPP berfungsi sebagai jaring pengaman agar harga gabah petani tidak jatuh bebas di bawah harga yang telah dipatok oleh pemerintah. Bulog merupakan institusi yang diberikan kewenangan oleh pemerintah untuk mengamankan sekaligus representasi jaminan pasar bagi gabah beras petani. Adapun perkembangan HPP beras dapat dilihat pada Gambar 6 .

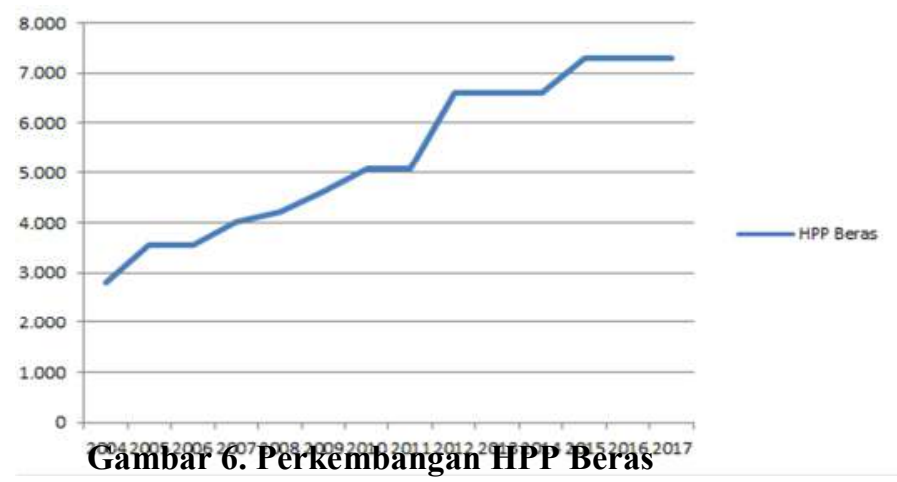

Selama tahun 2004-2017, Instruksi Presiden (Inpres) mengenai HPP ini sudah terbit sebanyak 9 (sembilan) kali. Inpres tersebut dibuat berdasarkan kondisi tertentu, yang semuanya bertujuan untuk melindungi petani padi dari turunnya harga output dan turunnya pendapatan usahatani padi. Inpres terakhir yang terbit pada tahun 2015 adalah Inpres No. 5/2015 tentang Kebijakan Pengadaan Gabah/Beras dan PenyaluranBerasolehPemerintah.

\section{Investasi Irigasi}

Selama rentang waktu penelitian (2004-2017), jaringan irigasi yang sudah terealisasi dapat dilihat pada Gambar 7. 


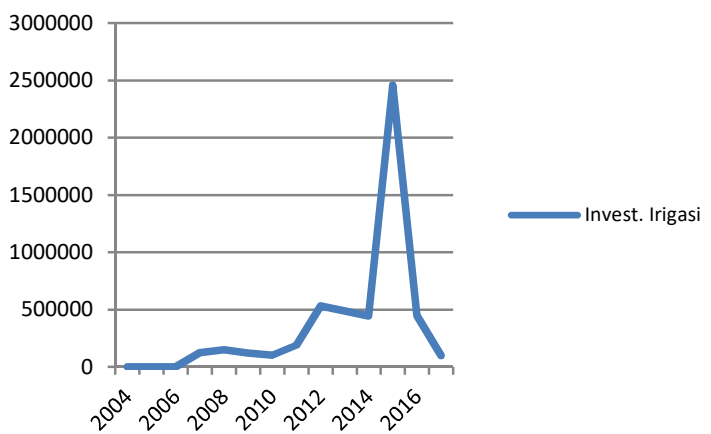

Gambar 7. Perkembangan Investasi Irigasi

Berdasarkan gambar di atas, berdasarkan tahun pengamatan, investasi irigasi pemerintah mengalami fluktuasi dalam pengembangannya. Hanya tahun 2012 dan 2015 mengalamipeningkatan yang cukup signifikan dari tahun sebelumnya yaitu mencapai $180,90 \%$ dan $453,91 \%$ dibanding tahun sebelumnya. Terutama di tahun 2015, peningkatan yang sangat tinggi tersebut disebabkan perhatian pemerintah yang sangat besar melalui program Upaya Khusus Padi Jagung Kedelai (UPSUS PAJALE). Adapun program pokok di dalam UPSUS swasembada padi/beras adalah perbaikan jaringan irigasi tersier. Pada tahun anggaran (TA) 2015 telah dialokasikan kegiatan pengembangan jaringan irigasi seluas 2.478.182 Ha dan terealisasi seluas 2.458.471 Ha (99,20\%).

\section{Cetak Sawah}

Cetak sawah merupakan usaha pemerintah dalam rangka mengimbangi aktifitas konversi lahan pertanian yang terus berlangsung sampai saat sekarang ini dan sekaligus bentuk terobosan pemerintah demi memperkuat ketahanan pangan nasional. Adapun perkembangan cetak sawah dapat dilihat padaGambar8.

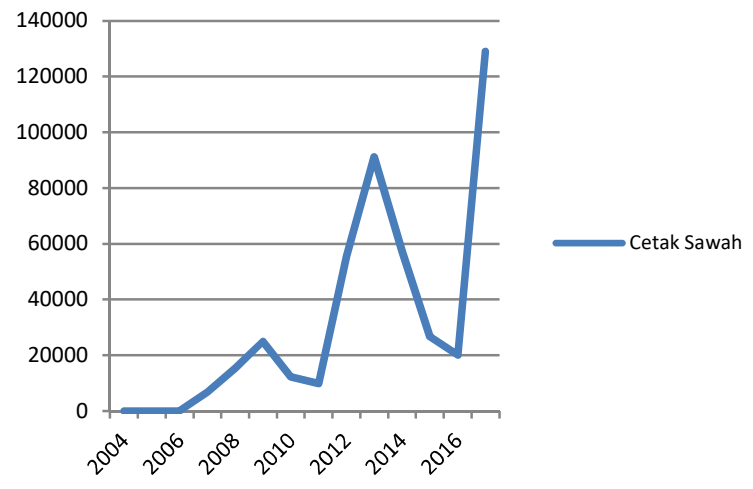

Gambar 8. Perkembangan Cetak Sawah

Kegiatan cetak sawah yang dilaksanakan oleh pemerintah lebih banyak dilakukan di luar pulau Jawa karena masih berpotensi dari segi kecukupan luasnya untuk dijadikan lahan pertanian. Dari data di atas, setiap tahunnya pemerintah baru bisa mencetak sawah sekitar $40.833 \mathrm{Ha}$. Tentunya angka tersebut belum bisa mengganti lahan yang sudah dikonversi yang bisa mencapai angka 100.000 ha. Angka pertumbuhan tertinggi tercatat di tahun 2017, yaitu sebesar 129.097 ha. Peningkatan tersebut merupakan bagian dari program UPSUS Padi.

\section{Perkembangan Penduduk}

Jumlah penduduk Indonesia selalu meningkat setiap tahunnya berdasarkan data dari BPS. Oleh sebab itu, secara otomatis pemerintah harus menyediakan beras sesuai dengan kebutuhan dan 
perkembangan penduduk Indonesia. Selama tahun 2004-2017, rata-rata pertumbuhan penduduk Indonesia mencapai $1,23 \%$ per tahun. Perkembangan populasi penduduk Indonesia dari tahun 2004-2017 disajikan pada Gambar 9.

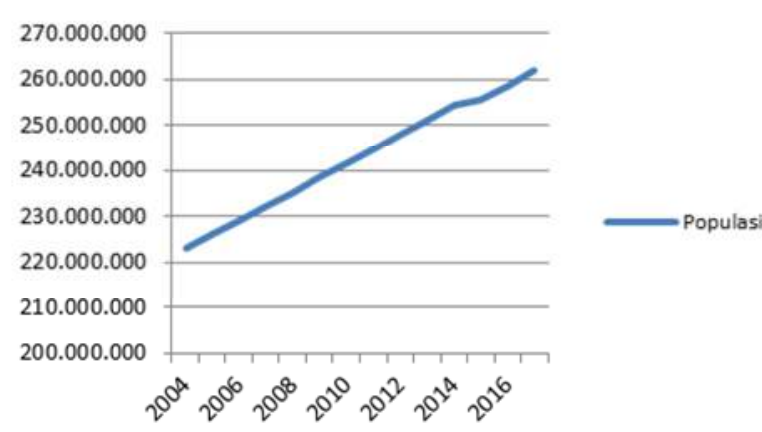

Gambar 9. Perkembangan Populasi Indonesia tahun 2004-2017

\section{Perkembangan Impor}

Ketergantungan Indonesia terhadap beras impor termasuk masih rendah, yaitu kurang dari 5\%. Hal tersebut bisa dilihat di Gambar 10 .

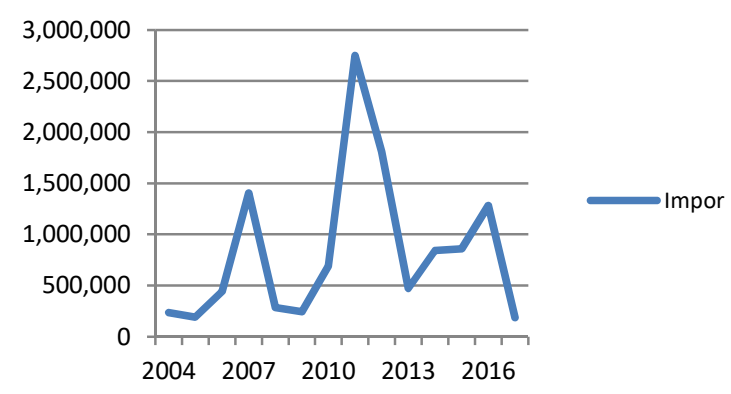

Gambar 10. Perkembangan Impor Beras Tahun 2004-2017

Gambar di atas menunjukkan bahwa impor Indonesia memiliki nilai yang fluktuatif. Berdasarkan tahun pengamatan (2004-2017), rerata Indonesia mengimpor sebanyak 835.233 ton setiap tahunnya dengan rasio terhadap total produksi dalam negeri sebesar 2,01\%. Hanya saja pada tahun 2007, 2011, 2012 dan 2016 impor Indonesia mencapai di atas 1 juta ton. Pemerintah tetap mengimpor beras di atas 1 juta ton pada tahun 2007, 2012 dan 2016 meskipun sudah terjadi peningkatan produksi beras, hal tersebut dikarenakan oleh kebijakan pemerintah untuk mengantisipasi terjadinya kemungkinan berkurangnya persediaan beras akibat bencana alam (misalnya el-nino), lonjakan harga pada tahun sebelumnya maka pemerintah melakukan kontrak impor dengan negara produsen beras pada tahun sebelumnya.

\section{Faktor Memengaruhi Ketersediaan Beras dengan Analisis Jalur (Path Analysis)}

1. Analisis Kelayakan Model Jalur (Path Modelling)

Terdapat 13 variabel terlibat didalam model yang diukur di dalam penelitian ini, terdiri atas variabel dependen, independen dan variabel intervening, yaitu ketersedian, produksi, subsidi benih, harga pupuk subsidi urea, harga pupuk subsidi SP-36, harga pupuk subsidi ZA, harga pupuk subsidi NPK, HPP beras, cetak sawah, investasi irigasi, tarif impor, populasi, dan impor.

Hasil penilaian path model menggunakan STATA Version 12 dari 
Base Model dari ketersediaan beras di Indonesia diilustrasikan pada Gambar 11.

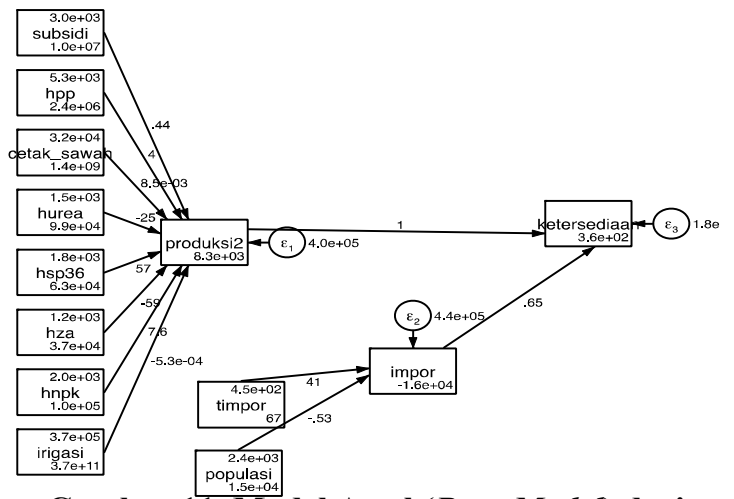

Gambar 11. Model Awal (Base Model) dari Ketersediaan Beras di Indonesia

Model akan dianalisi dengan Structural Equational Modelling (SEM) menggunakan program STATA (Tabel 1).

Tabel 1. Nilai Base Model Ketersediaan Beras di Indonesia

\begin{tabular}{clccc}
\hline $\begin{array}{c}\text { Variabel } \\
\text { Endogenous }\end{array}$ & $\begin{array}{c}\text { Variabel } \\
\text { Eksogenous }\end{array}$ & $\begin{array}{c}\text { Path } \\
\text { coefficient }(\beta)\end{array}$ & z-value & $\mathrm{P}>|\mathrm{z}|$ \\
\hline produksi & subsidi & 0,441 & 3,78 & 0,000 \\
\hline & hpp & 4,009 & 6,56 & 0,000 \\
\hline & cetak sawah & 0,008 & 1,03 & 0,304 \\
\hline & hurea & -24.577 & $-3,77$ & 0,000 \\
\hline & hsp36 & 56,613 & 1,26 & 0,207 \\
\hline & hza & $-58,509$ & $-0,86$ & $-0,390$ \\
\hline & hnpk & 7,575 & 1,45 & 0,148 \\
\hline impor & irigasi & $-0,0005$ & $-1,29$ & 0,196 \\
\hline & timpor & 40,508 & 1,30 & 0,193 \\
\hline ketersediaan & populasi & $-0,534$ & $-0,25$ & 0,801 \\
\hline produksi & 0,998 & 45,55 & 0,000 \\
\hline signifikansi $a=0,10$ & impor & 0,647 & 4,08 & 0,000 \\
\hline
\end{tabular}

Sumber: Analisis Data Sekunder (2018)

Hasil analisis STATA harus diuji dengan indeks kesesuaian atau ketepatan dengan menggunakan Root mean squared error of approximation (RMSEA), comparative fit Index (CFI) and Tucker Lewis index (TLI) (Tabel 2).

Tabel 2. Uji Ketepatan Model Awal

\begin{tabular}{|l|c|c}
\hline \multicolumn{1}{c}{ Indeks } & Value & Interpretasi \\
\hline RMSEA & 0,605 & Poor Fit \\
\hline CFI & 0,501 & Poor Fit \\
\hline TLI & 0,314 & Poor Fit \\
\hline
\end{tabular}

Sumber : Analisis Data Sekunder (2018)
Model dinyatakan tidak fit sehingga diperlukan modifikasi model dengan mengeluarkan variabel yang tidak signifikan ditandai dengan nilai signifikansi z nya lebih dari derajat bebas 0,10 yaitu variabel cetak sawah, harga pupuk SP36 subsidi, harga pupuk ZA subsidi, harga pupuk NPK subsidi, investasi irigasi, tarif impor dan populasi.

Variabel cetak sawah, harga pupuk SP-36 dan ZA, serta populasi dikeluarkan dari model karena memiliki nilai signifikansi $\mathrm{z}$ yang paling tinggi dengan kata lain variabel tersebut tidak signifikan didalam model ketersediaan. Selanjutnya dilakukan modifikasi model dan dilanjutkan dengan uji ketepatan dengan hasil seperti terlihat pada Tabel 3.

Tabel 3. Nilai Model Ketersediaan Beras di Indonesia Hasil Modifikasi

\begin{tabular}{|c|c|c|c|c|}
\hline $\begin{array}{c}\text { Variabel } \\
\text { Endogenous }\end{array}$ & $\begin{array}{c}\text { Variabel } \\
\text { Eksogenous }\end{array}$ & $\begin{array}{c}\text { Path } \\
\text { coefficient }(\beta)\end{array}$ & z-value & $P>|z|$ \\
\hline \multirow[t]{5}{*}{ produksi } & subsidi & 0,328 & 2,53 & 0,011 \\
\hline & hpp & 4,179 & 8,33 & 0,000 \\
\hline & hurea & $-15,710$ & $-3,84$ & 0,000 \\
\hline & hnpk & 9,225 & 2,84 & 0,005 \\
\hline & irigasi & $-0,001$ & $-2,04$ & 0,041 \\
\hline impor & timpor & 34,845 & 1,61 & 0,107 \\
\hline \multirow[t]{2}{*}{ ketersediaan } & produksi & 0,998 & 45,55 & 0,000 \\
\hline & impor & 0,647 & 4,08 & 0,000 \\
\hline
\end{tabular}

Signifikansi $a=0,10$

Sumber: Analisis Data Sekunder (2018)

Tabel 4. Uji Ketepatan Model Final

\begin{tabular}{l|l|c}
\hline \multicolumn{1}{c|}{ Indeks } & Value & Interpretasi \\
\hline RMSEA & 0,177 & Poor Fit \\
\hline CFI & 0,948 & Good Fit \\
\hline TLI & 0,927 & Good Fit \\
\hline
\end{tabular}

Sumber: Analisis Data Sekunder (2018) 
Model menunjukkan dapat diterima, meskipun RMSEA masih menunjukkan 'poor fit" hal tersebut bisa disebabkan oleh ukuran sampel relatif sedikit. Hasil modifikasi final dapat dilihat pada Gambar 12.

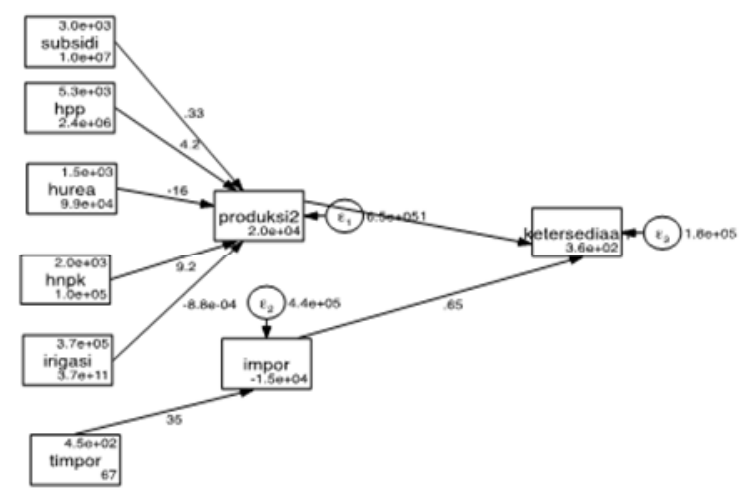

Gambar 12. Model Final dari Ketersediaan Beras di Indonesia

Persamaan struktural dari model akhir adalah sebagai berikut:

- Produksi $=20368,33+0,328$ subsidi + 4,179hpp - 15,710hurea +9,225hnpk0,001 irigasi $+\varepsilon_{1}$

- Impor $=-14695,73+34,845$ timpor + $\varepsilon_{2}$

- Ketersediaan $=363,910+0,998$ produksi $+0,647$ impor $+\varepsilon_{3}$

\section{Interpretasi hasil pengaruh langsung (Direct effects)}

Variabel yang berpengaruh langsung dan signifikan terhadap produksi adalah subsidi benih padi, HPP beras, harga pupuk urea subsidi harga pupuk NPK subsidi dan investasi irigasi.

Variabel subsidi benih menunjukkan nilai unstandardized path coefficient $\beta_{11}$ $0,328(\mathrm{z}=2,53)$. Hal tersebut mengindika- sikan bahwa subsidi benih secara langsung dan signifikan dapat meningkatkan produksi beras. Hasil tersebut sesuai dengan hasil penelitian Riefqi et.al (2017) yang menyatakan bahwa petani yang menggunakan benih padi subsidi memiliki tingkat produktivitas dan pendapatan yang lebih tinggi dibandingkan dengan petani yang menggunakan benih padi tidak bersubsidi. Tujuan dari kebijakan subsidi benih tersebut dikeluarkan yaitu membantu petani agar dapat membeli benih varietas unggul tercapai. Hasil di atas memberikan gambaran kepada pemerintah untuk terus mempertahankan program subsidi benih ini karena manfaatnya sangat dirasakan oleh petani di lapangan.

Variabel HPP beras berpengaruh langsung dan signifikan terhadap produksi beras dengan unstandardized coefficient $\beta_{12} 4,179 \quad(\mathrm{z}=8,33)$. Dengan adanya kebijakan HPP ini, produksi beras Indonesia dapat meningkat, karena akan merangsang petani untuk berproduksi padi/beras. Hal tersebut ditunjang oleh hasil penelitian Putri et.al (2013) yang menjelaskan bahwa hasil simulasi dari dampak kebijakan peningkatan HPP gabah masing-masing $9,45 \%$ dan $15 \%$ akan memberikan insentif kepada petani dalam meningkatkan produktivitasnya dan produksi padi masing-masing $0,01 \%$ dan 
$0,26 \%$. Peningkatan produsi padi menyebabkan produksi beras juga meningkat sebesar $0,26 \%$. Hasil positif yang ditunjukkan oleh variabel HPP beras ini merupakan tanda yang diberikan oleh pelaku usaha (petani) untuk tetap diteruskan dan ditingkatkan nilainya yang sesuai dengan perkembangan harga pasar.

Selain itu produksi juga dipengaruhi oleh variabel harga pupuk urea subsidi dengan standardized coefficient $\beta_{13}$ 15,710 $(z=-3,84)$. Nilai variabel tersebut menunjukkan bahwa dampak peningkatan harga pupuk urea subsidi berpengaruh langsung dan signifikan terhadap produksi padi. Hal tersebut bisa dimengerti karena kebutuhan urea untuk tanaman padi termasuk yang paling banyak jumlahnya, menurut BB Padi untuk 1 Ha lahan sawah memerlukan $300 \mathrm{~kg}$ pupuk urea, $100 \mathrm{~kg}$ pupuk SP36 dan $100 \mathrm{~kg}$ pupuk $\mathrm{KCl}$ (www.bbpadi.litbang.pertanian.go.id).

Dengan naiknya harga pupuk urea terpaksa petani harus mengurangi pemakaian pupuk urea yang akan berdampak pada penurunan produktivitas dan produksi. Peningkatan harga ini tentunya menjadi beban oleh petani yang rata-rata merupakan petani kecil. Untuk itu pemerintah harus tetap menjaga stabilitas harga pupuk urea subsidi ini.
Produksi juga dipengaruhi juga dengan variabel harga pupuk NPK dengan unstandardized coefficient $\beta_{14}$ 9,225 ( $\mathrm{z}=$ 2,84). Variabel ini kebalikan dengan variabel urea. Harga pupuk NPK berpengaruh lansung dan signifikan terhadap produksi beras Indonesia. Hal tersebut dikarenakan fungsi atau manfaat dari pupuk NPK adalah salah satunya meningkatkan produksi, sehingga kenaikan harga tidak memengaruhi konsumsi terhadap pupuk NPK.

Variabel investasi irigasi juga memengaruhi produksi secara langsung dan signifikan dengan unstandardized coefficient $\beta_{15}-0,001(\mathrm{z}=-2,04)$ terhadap produksi beras. Nilai variabel tersebut menunjukkan bahwa dampak invenstasi irigasi berpengaruh negatif terhadap produksi padi. Hal tersebut bisa saja terjadi, menurut Sutrisno dan Heryani (2015), adanya kendala fenomena alam seperti perubahan iklim yang menyebabkan ketidakpastian ketersediaan air, keterbatasan sumber daya lahan dan air untuk pengembangan irigasi, degradasi lahan yang menyebabkan penurunan sumber daya lahan dan air serta pengaruh sosial ekonomi dan budaya setempat. Sehingga irigasi yang dibangun belum bisa memberikan pengaruh terhadap 
peningkaran produksi padi/beras di Indonesia.

Sementara variabel impor, berdasarkan hasil olah dari program STATA menunjukan tidak signifikannya variabel eksogenous tarif impor memengaruhi impor dilihat dari nilai signifikasinya melebihi 0,10. Tetapi dalam model variabel tarif impor ini tetap dipakai dalam model karena bisa memengaruhi kelayakan model. Variabel tarif impor nilai unstandardized coefficient $\beta_{21} 34,845$ ( $\mathrm{z}=$ 1,61). Hasil tersebut berlawan dengan teori yang menyatakan yang dinyatakan oleh Kindleberger dan Lindert (1983), alasan pemerintah yang memilih menggunakan tarif untuk membatasi impor. Berpengaruh positifnya tarif impor terhadap impor sejalan dengan penelitian Malik dan Wulandari (2007) yang menghasilkan tarif impor tidak berpengaruh negatif terhadap impor tetapi berpengaruh positif. Hal tersebut bisa dipahami bahwa tarif impor yang diterapkan oleh pemerintah masih dikatakan sangat kecil. Sehingga pengaruhnya tidak signifikan terhadap penurunan impor.

Sedangkan variabel produksi dan impor menunjukkan pengaruh langsung dan signifikan untuk ketersediaan. Variabel produksi dengan $\beta_{31} \quad 0,998 \quad(z=45,55)$ menunjukkan bahwa setiap peningkatan produksi akan meningkatkan ketersediaan beras. Begitu juga dengan impor menunjukkan nilai $\beta_{32} 0,647(\mathrm{z}=4,08)$, yang berarti impor berpengaruh langsung dan signifikan teradap ketersediaan beras. Hasil tersebut sesuai dengan UU No. 18 tahun 2012 tentang Pangan pasal 14 ayat 1 dan 2 yang menyatakan sumber ketersediaan pangan, dalam hal ini beras, berasal dari produksi dalam negeri dan impor.

\section{Interpretasi model pengaruh tidak langsung (indirect effects)}

Variabel-variabel yang memengaruhi secara langsung terhadap produksi dan impor berpengaruh terhadap ketersediaan secara tidak langsung.

\begin{tabular}{|c|c|c|c|c|c|c|}
\hline Tabel 5 & $\begin{array}{c}\text { Direct } \\
\text { Predi } \\
\text { Beras }\end{array}$ & $\begin{array}{l}\text { dan } \\
\text { ktor }\end{array}$ & $\begin{array}{l}\text { direct } \\
\text { rhada| }\end{array}$ & $\begin{array}{l}\text { Effect } \\
\text { Kete }\end{array}$ & $\begin{array}{l}\text { Vari } \\
\text { rsedi }\end{array}$ & $\begin{array}{l}\text { bel } \\
\text { aan }\end{array}$ \\
\hline $\begin{array}{l}\text { Variabel } \\
\text { Endogenous }\end{array}$ & $\begin{array}{c}\text { Variabel } \\
\text { Eksogenous }\end{array}$ & $\begin{array}{c}\text { Unstandard } \\
\text { ized direct } \\
\text { effect }\end{array}$ & $\begin{array}{c}\text { Unstanda } \\
\text { rdized } \\
\text { indireet } \\
\text { effect }\end{array}$ & $\begin{array}{l}\text { Unstandar } \\
\text { dized total } \\
\text { effect }\end{array}$ & $\begin{array}{c}z- \\
\text { value }\end{array}$ & $P>|z|$ \\
\hline \multirow[t]{5}{*}{ produksi } & subsidi & 0,328 & & 0,328 & 2,53 & 0,011 \\
\hline & hpp & 4,179 & & 4,179 & 8,33 & 0,000 \\
\hline & hurea & $-15,710$ & & $-15,710$ & $-3,84$ & 0,000 \\
\hline & hnpk & 9,225 & & 9,225 & 2,84 & 0,005 \\
\hline & irigasi & $-0,001$ & & $-0,001$ & $-2,04$ & 0.041 \\
\hline impor & timpor & 34.845 & & 40.508 & 1.161 & 0.107 \\
\hline \multirow{8}{*}{ ketersediaan } & produksi & 0.998 & & 0.998 & 45.55 & 0.000 \\
\hline & impor & 0,647 & & 0.647 & 4.08 & 0,000 \\
\hline & subsidi & & 0.328 & 0.328 & 2.53 & 0.012 \\
\hline & hpp & & 4,173 & 4,173 & 8,20 & 0.000 \\
\hline & hurea & & -15.686 & -15.686 & -3.82 & 0.000 \\
\hline & hnpk & & 9,211 & 9,211 & 2,83 & 0.005 \\
\hline & irigasi & & -0.001 & 0.001 & -2.04 & 0.041 \\
\hline & timpor & & 22.537 & 22.537 & 1.50 & 0.133 \\
\hline
\end{tabular}

Berdasarkan nilai-nilai dari tabel, misalnya koefisien variabel subsidi benih yang berpengaruh secara langsung terhadap produksi adalah 0,328 , sementara koefisien variabel produksi yang 
berpengaruh langsung terhadap ketersediaan adalah 0,998, sehingga total efek subsidi benih terhadap ketersediaan beras Indonesia adalah $0,328(\mathrm{z}=0,328 \times 0,998)$ yang ditransmisikan oleh produksi. Dilihat dari nilai probabilitinya jika dibandingkan dengan taraf kepercayaan 0,10 , variabel subsidi benih secara tidak langsung berpengaruh signifikan terhadap ketersedian beras.

Sama dengan subsidi, variabel HPP, harga urea dan NPK subsidi, dan irigasi yang berpengaruh secara langsung terhadap produksi dengan nilai koefisien secara berturut-turut adalah 4,$179 ;-15,710$; 9,225; dan -0,001. Sehingga total efek variabel-variabel tersebut terhadap ketersediaan secara berturut-turut adalah 4,173 (4,179 x 0,998); -15,686 (-15,710 × 0,998); $9,211(9,225 \times 0,998)$ dan $-0,001(-0,001 \times$ 0,998). untuk nilai probabilitas masingmasing variabel tersebut lebih kecil dari taraf nyata 0,10 . Sehingga variabelvariabel tersebut berpengaruh signifikan terhadap ketersediaan beras Indonesia yang ditransmisikan melalui variabel produksi.

Sementara untuk variabel impor yang dipengaruhi secara langsung oleh tarif impor dengan nilai 34,845, sedangkan koefisien variabel impor yang berpengaruh terhadap ketersediaan beras adalah 0,647, sehingga total efek tarif impor terhadap ketersediaan beras adalah 22,537 yang ditransmisikan oleh impor.

\section{KESIMPULAN DAN SARAN}

\section{Kesimpulan}

Berdasarkan analisis jalur (path analysis) terhadap model ketersediaan beras Indonesia, didapatkan ada 2 (dua) variabel berpengaruh langsung dan signifikan terhadap ketersediaan, yaitu produksi dan impor. Untuk variabel produksi beras dipengaruhi secara langsung oleh 5 (lima) variabel, yaitu subsidi benih padi, HPP beras, harga pupuk urea subsidi, harga pupuk NPK subsidi dan investasi irigasi. Sedangkan untuk impor dipengaruhi secara langsung oleh tarif impor. Pengaruh masing-masing variabel bebas yang memengaruhi produksi dan impor menunjukkan pengaruhnya secara tidak langsung terhadap ketersediaan beras di Indonesia.

\section{Saran}

a. Produksi beras dalam negeri tentunya sumber utama ketersedian beras dalam negeri Indonesia harus selalu dijaga pertumbuhannya dengan terus meningkatkan perhatian pemerintah dengan lebih memantapkan kebijakankebijakan yang berefek langsung 
terhadap peningkatan produksi beras seperti subsidi benih, HPP beras, harga pupuk urea subsidi, subsidi pupuk NPK subsidi, dan investasi irigasi.

b. Impor juga menjadi tumpuan alternatif untuk memenuhi ketersediaan beras di Indonesia setelah produksi dalam negeri dan cadangan beras tidak mencukupi ketersediaan beras. Tetapi impor harus tetap dikendalikan dengan tetap memberlakukan tarif impor terhadap bahan pangan pokok terutama beras sehingga bisa melindungi petani padi dari serbuan. Tarif impor yang ada tersebut masih bisa ditingkatkan sejauh masih dalam skema tarif yang diperbolehkan oleh WTO yaitu batas tertinggi $160 \%$ untuk beras.

\section{DAFTAR PUSTAKA}

Augusty, F. (2005). Structure Equation Modeling dalam Penelitian Managemen. Badan Penerbit Universitas Diponegoro. Semarang.

Clapp, J. (2016). Food self-sufficiency: Making Sense of It, And When It Makes Sense [Jurnal]. journal homepage:

www.elsevier.com/locate/ foodpol
Kementan. (2012). Undang-Undang Nomor 18 Tahun 2012 tentang Pangan. Jakarta.

Kementan. (2015). Rencana Strategis Kementerian Pertanian Tahun 20152019.Jakarta.Kementan RI.

Lindert and Kindleberger. 1983. Ekonomi Internasional. Edisi Ketujuh. Jakarta: Penerbit Erlangga.

Malik, N. dan Wulandari, K. (2007). Analisis Dampak Tarif Impor Terhadap Perkembangan Neraca Perdagangan Indonesia (Periode 1995.1 - 2005.4). Journal of Innovation in Business and Economics, 16(26): 1119-1144.

Putri, Eka Intan K., Novindra., dan Nuva. (2013). Dampak Kebijakan Harga Pembelian Petani Gabah terhadap Kesejahteraan Petani: Suatu Simulasi. Jurnal Ekonomi Pembangunan Indonesia, 13(2): 125134.

Riefqi, Azka Radietthya., Memen Surahman., Hastuti. (2017). Pengaruh Benih Padi (Oryza sativa L.) Bersubsidi terhadap Produksi dan Pendapatan Petani Padi Sawah. Bul. Agrohorti, 5(1): 1-8.

S.A. Zukhri Agusty Leo. (2000). Analisis Respon Penawaran Padi Indonesia. Fakultas Pertanian. IPB. Bogor.

Wahyu dan Iwan Setiawan. (2017). BUMN Pangan. Jakarta. Penebar Swadaya. $255 \mathrm{p}$.

www.bbpadi.litbang.pertanian.go.id 